\title{
The Impact of Microbiological Pollutants on School Indoor Air Quality
}

\author{
Peter Fsadni' ${ }^{1}$, Bezzina Frank ${ }^{2}$, Claudia Fsadni' ${ }^{1}$, Stephen Montefort ${ }^{1}$ \\ ${ }^{1}$ Department of Medicine, Faculty of Medicine and Surgery, University of Malta, Msida, Malta \\ ${ }^{2}$ Faculty of Economics, Management and Accountancy, University of Malta, Msida, Malta \\ Email: peter.fsadni@um.edu.mt
}

How to cite this paper: Fsadni, P., Frank, B., Fsadni, C. and Montefort, S. (2017) The Impact of Microbiological Pollutants on School Indoor Air Quality. Journal of Geoscience and Environment Protection, 5, 54-65

https://doi.org/10.4236/gep.2017.55004

Received: April 18, 2017

Accepted: May 19, 2017

Published: May 22, 2017

Copyright (๑ 2017 by authors and Scientific Research Publishing Inc. This work is licensed under the Creative Commons Attribution International License (CC BY 4.0).

http://creativecommons.org/licenses/by/4.0/ c) $\underset{\mathrm{EY}}{0}$ Open Access

\begin{abstract}
Asthma is common in children with allergens and mould influencing the development of the disease. Since children spend most of their time outside their homes within the school environment, school indoor air quality can directly influence their respiratory health. This study aims to identify microbiological contaminants in Maltese schools. The association between contaminants, respiratory health and school characteristics has been analysed. Five primary schools were selected with 9 to 11 years old students participating. Standardised health questionnaires, lung function tests, and school characterisation were performed. Dust samples were analysed for fungi, bacteria and allergens were performed. Penicillium/Aspergillus/Paecilomyces/Variotii (PenAsp) group had the highest median indoor concentration followed by Mycobacterial and Streptomyces species. There was a significant negative correlation between PenAsp and Mycobacterium spp levels in all the participating schools ( $r=$ $-0.42 ; \mathrm{p}=0.03)$. Cat allergen in classroom dust correlated positively with the number of cat owners $(r=0.43 ; \mathrm{p}=0.041)$. High exposure to fungi, bacteria and allergens was significantly associated with upper and lower airway atopy. School/classroom characteristics and cleaning protocols were significantly associated with exposure to these pollutants. In conclusion, fungi, bacteria, endotoxin, cat and dog allergens have been found to have a direct influence on school indoor air quality in the Maltese Islands. A significant association was observed between these contaminants and upper and lower airway atopy. Specific school, classroom, cleaning and maintenance characteristics have been identified as having a direct impact on indoor air quality.
\end{abstract}

\section{Keywords}

Asthma, Mould, School, Bacteria

\section{Introduction}

Asthma is a common allergic disease in children and allergens secondary to 
house dust mite, cockroach, cats, dogs and fungi are considered as potential contributors to the development or progression of the disease [1]. Mould in the school environment was associated with asthma [2] and Aspergillus spp resulted in a decrease in nasal patency and increased ECP and lysozyme nasal lavage (NAL) levels [3]. The HESE Study showed a significant positive correlation between the prevalence of wheezing and Aspergillus/Penicillium DNA, while $A s$ pergillus versicolor DNA correlated positively with wheeze, rhinitis, and cough [4]. Since there is no data about biological contamination of schools located in island nations such as Malta, this study aims to provide new data about the microbiological and allergic contamination of primary schools located in the Maltese Islands which have very specific geographical and environmental characteristics. It is difficult to extrapolate data to different regions of the world due to unique microenvironments. This data will help in the improvement of school indoor air quality both in Malta and in countries having similar environmental characteristics.

\section{Materials and Method}

\subsection{Data Collection}

Five primary state schools were selected randomly from five geographical clusters of schools designated north, south, central, east and west. Three classrooms within each school were selected among the 9 to 11 year age group with all students asked to participate. The classrooms were randomly selected by ballot system so as to eliminate potential bias. Primary state schools in Malta are coeducational.

\subsection{Ethical Approval and Consent}

This study was approved by the University of Malta Research Ethics Committee and the Education Department Research Directorate.

\subsection{Health Assessment and School Characterisation}

Standardised health questionnaires focusing on wheezing, rhinitis and eczema based on ISAAC [5] were answered by the children's parents. Lung function tests, acoustic rhinometry, exhaled NO, exhaled $\mathrm{CO}$ and nasal lavage were performed on the participating children. Characterisation of each participating school was performed focusing on the school building, classrooms, cleaning/ maintenance protocols and the outdoor environment.

\subsection{Microbiology and Allergens}

Dust samples were collected from each of the selected classrooms. Settled dust was vacuumed from surfaces above floor level into dust sampling socks while electrostatic dust fall collectors were used for the passive sampling of airborne dust onto electrostatic wipes. Floor dust was collected using ALK adaptors and filter cassettes fitted to vacuum cleaners. Indoor levels of endotoxin were deter- 
mined using the limulus ameobocyte assay [6].

Microbiological species investigated in this study included Aspergillus versicolor (Avers), Cladosporium herbarum (Cherb), Alternaria alternata (Aaltr) and Trichoderma viride (Tviri), a larger fungal group comprising Penicillium spp./ Aspergillus spp./Paecilomyces spp. (PenAsp), as well as the two bacterial genera Streptomyces spp. (Strep) and Mycobacterium spp. (Myco). These were analyzed using quantitative polymerase chain reaction (qPCR) techniques [7]. Allergen levels were determined using two-site sandwich ELISA for house dust mite (Der $\mathrm{p} 1$, Der f1), cat (Fel d1), dog (Can f1) while horse allergen (Equ cx) was measured using monoclonal antibodies [8] [9]. Due to the lack of established guidelines, data has been reported in quartiles and schools having indoor concentrations within the upper quartile were considered as having elevated levels of the particular microbiological or allergen contaminant.

\subsection{Statistical Analysis}

Data was transferred to IBM SPSS Statistics version 21 (Inc., Chicago, IL) for analysis. For statistical significance, a p-value cut off point of 0.05 was adopted. In the case of multiple comparisons, the Bonferroni correction was applied to avoid inflation of the Type 1 error. Regression analysis was used to eliminate any possible confounding factors.

\section{Results}

\subsection{Indoor Microbiological Agents}

A total of 15 classrooms $(n=15)$ in 5 schools were studied. Local results have been compared to the SINPHONIE data [10] since similar methodology was used. Penicillium/Aspergillus/ Paecilomyces/Variotii (PenAsp) group in this study had the highest median indoor concentration followed by the Mycobacterial and Streptomyces species Table 1. The highest levels of PenAsp organisms were seen in schools 1 and 2 ( $\mathrm{p}<0.001$ ) Figure 1 while schools 4 and 5 had the highest levels of Mycobacterium spp Figure 2. There was a significant negative correlation

Table 1. Indoor microbial pollutants (Bold figures represent those micro-organisms found at levels exceeding the SINPHONIE upper quartile threshold).

\begin{tabular}{cccccccc}
\hline Indoor Irritant & $\begin{array}{c}\text { SINPHONIE } \\
\text { Mean }\end{array}$ & $\begin{array}{c}\text { SINPHONIE } \\
\text { Median }\end{array}$ & $\begin{array}{c}\text { SINPHONIE } \\
\text { Upper Quartile }\end{array}$ & Mean & Median & SD & $\begin{array}{c}\text { Upper } \\
\text { Quartile }\end{array}$ \\
\hline eu_m-2 & 10080.1 & 7114.0 & 11578 & 4566 & 4343.96 & 2046.16 & 5971 \\
PenAsp-cells_mg-1 & 726149.3 & 63154.5 & 171013 & 6371237.67 & 3096125.4 & 6901398.1 & 12267648.96 \\
Avers-cells_mg-1 & 378.0 & 0.0 & 23 & 183.48 & 119.8 & 240.36 & 265.97 \\
Tviri-cells_mg-1 & 301.2 & 10.0 & 30 & 0.66 & 0 & 0.94 & 1.325 \\
Cherb-cells_mg-1 & 923.5 & 268.5 & 653 & 17.27 & 17.77 & 8.37 & 27.35 \\
Aaltr-cells_mg-1 & 39.2 & 8.0 & 20 & 1.04 & 0.69 & 1.19 & 2.1 \\
Strep-cells_mg-1 & 42252.7 & 16914.0 & 39617 & 13110.99 & 8611.66 & 12763.40 & 23704.28 \\
Myco-cells_mg-1 & 147504.4 & 51191.0 & 127465 & 25331.79 & 16969.09 & 23422.80 & 40791.93 \\
\hline
\end{tabular}




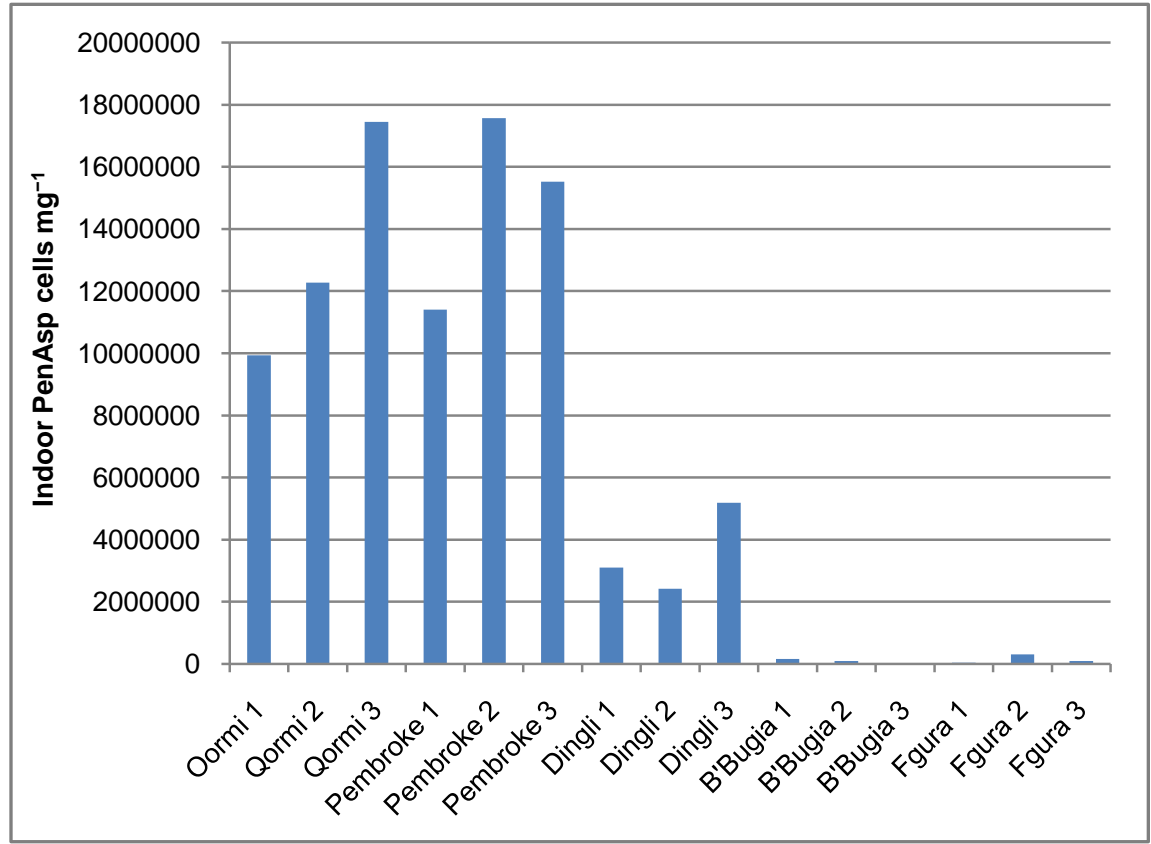

Figure 1. Indoor PenAsp levels.

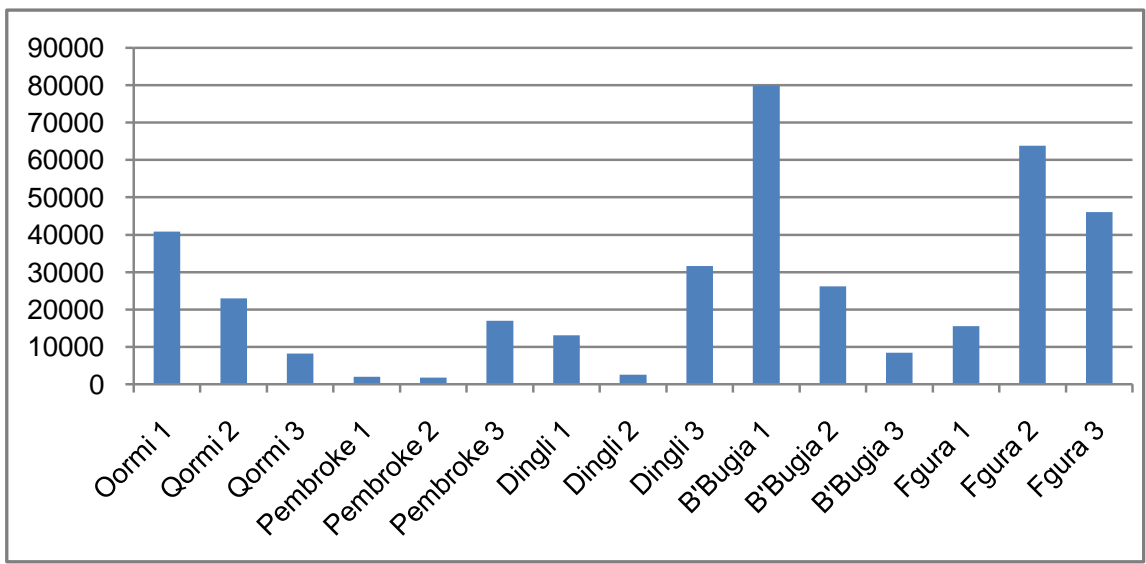

Figure 2. Indoor Mycobacterium spp levels.

between PenAsp and Mycobacterium spp levels in all the participating schools ( $r$ $=-0.42 ; \mathrm{p}=0.03)$ Figure 3. Mean Aspergillus versicolor levels (265.97 cells $/ \mathrm{mg}$ ) were higher than the SINPHONIE threshold of 23 cells/mg [10].

Trichoderma viridae levels varied considerably with school 1 having no organisms while other schools had levels above the upper quartile. All three classrooms in school 2 had consistently lower endotoxin levels compared to school 1 $(\mathrm{p}<0.001)$ Figure 4.

\subsection{Indoor Allergens}

Table 2 compares local allergen data to that from SINHONIE [10]. Four of the participating schools had cat allergen in classroom dust with school 5 exceeding the SINPHONIE upper quartile. Cat allergen levels correlated positively with the number of cat owners in each classroom $(r=0.43 ; \mathrm{p}=0.041)$. 


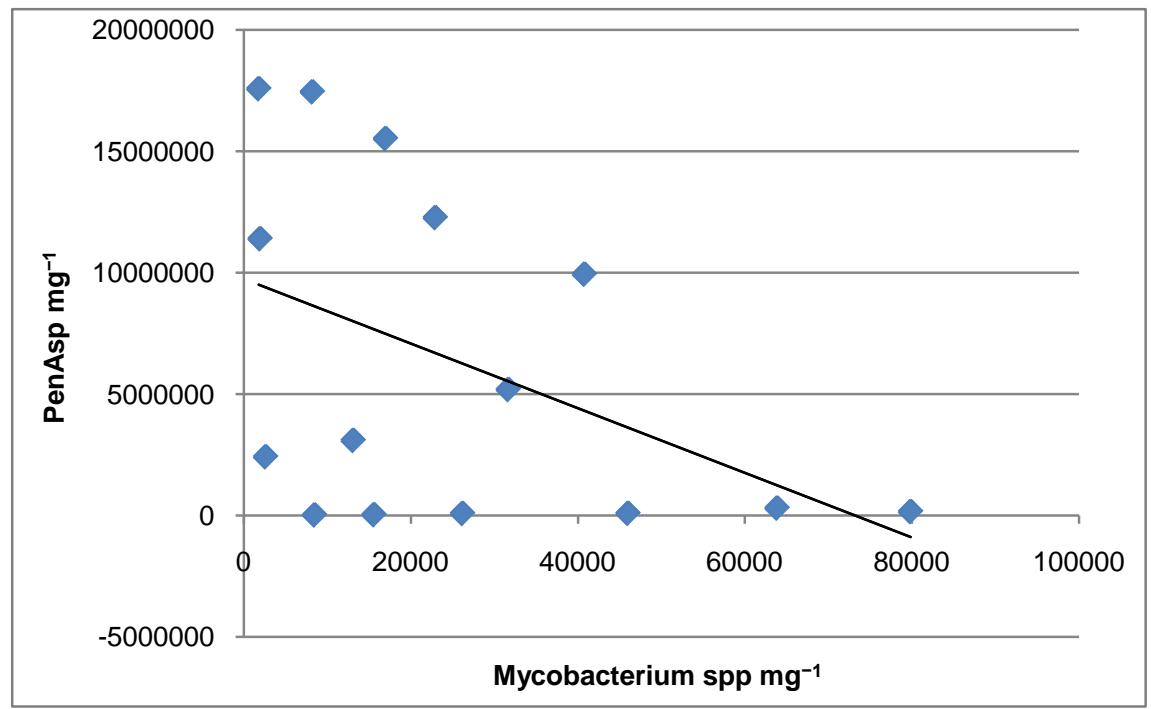

Figure 3. Correlation between PenAsp and Mycobacteria $(r=-0.42 ; \mathrm{p}=0.03)$.

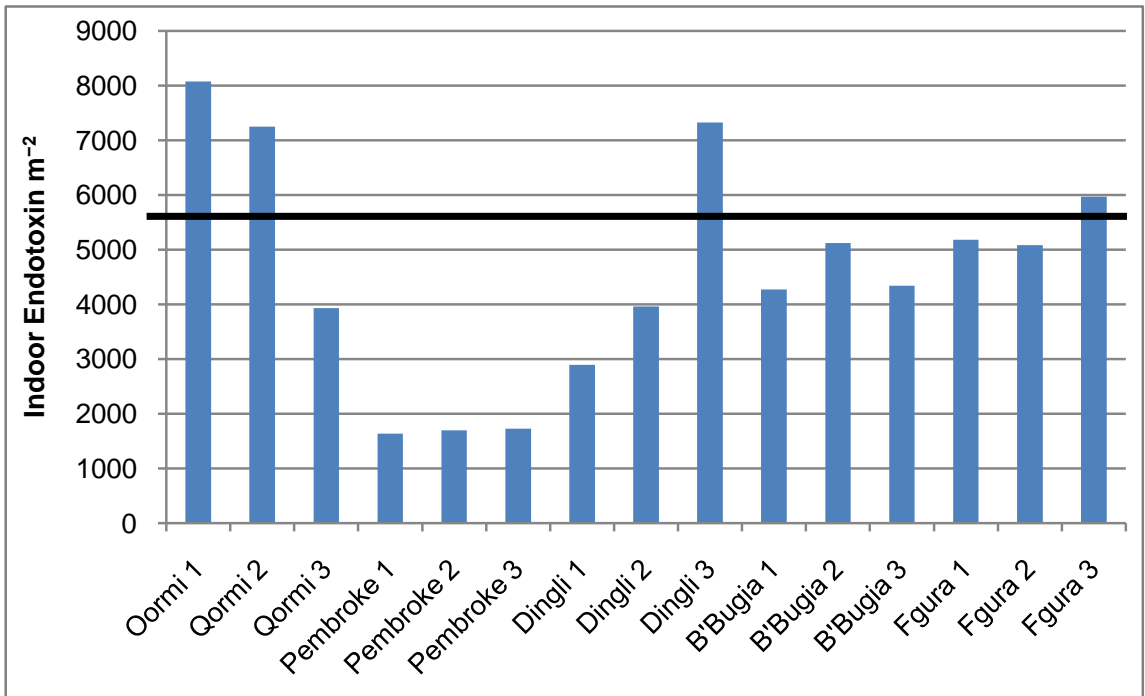

Figure 4. Indoor endotoxin levels.

Table 2. Indoor allergen levels.

\begin{tabular}{|c|c|c|c|c|c|c|c|}
\hline Indoor Allergen & $\begin{array}{c}\text { SINPHONIE } \\
\text { Mean }\end{array}$ & $\begin{array}{c}\text { SINPHONIE } \\
\text { Median }\end{array}$ & $\begin{array}{c}\text { SINPHONIE } \\
\text { Upper Quartile }\end{array}$ & Mean & Median & SD & $\begin{array}{c}\text { Upper } \\
\text { Quartile }\end{array}$ \\
\hline Catkonc_ng $g^{-1}$ & 86.5 & 0.0 & 101 & 38.17 & 0 & 59.85 & 79.53 \\
\hline Dogkonc_ng. $g^{-1}$ & 103.5 & 0.0 & 147 & 68.11 & 0 & 140.53 & 134.59 \\
\hline Horsekonc_ng. $g^{-1}$ & 80.3 & 0.0 & 0 & 0 & 0 & 0 & 0 \\
\hline Derp1konc_ng. $g^{-1}$ & 4.9 & 0.0 & 0 & 29.77 & 0 & 66.57 & 74.43 \\
\hline Derflkonc_ng. $g^{-1}$ & 2.8 & 0.0 & 0 & 0 & 0 & 0 & 0 \\
\hline
\end{tabular}

Three schools had dog allergens detected in samples taken from classroom dust with one class in each school having dog allergen levels superior to the SINPHONIE upper quartile. House dust mite Der p1 was detected in one classroom in school 3 with levels exceeding SINPHONIE upper quartile values. None 
of the schools had evidence of Der f1 and horse allergens.

\subsection{Association between High Exposure to Microbial Contaminants and Health in Children}

High exposure in this study was defined as indoor levels of pollutants above the second tertile of concentration. Endotoxin increased the risk of current rhinoconjunctivitis (OR 2.36, CI 1.65-9.4, $\mathrm{p}=0.026$ ), doctor diagnosed allergic rhinitis (OR 12.58, CI 1.27-14.91, $\mathrm{p}=0.006)$ and itchy skin rashes (OR 3.27, CI 1.16-10.07, $\mathrm{p}=0.031)$ which was more likely to resolve away from school (OR 6.15, 1.65$32.12, \mathrm{p}=0.029)$. High exposure to PenAsp microorganisms increased the risk of wheezing in the previous 12 months (OR 2.65, CI 1.78-9.87, p = 0.034). Aspergillus versicolor levels above the second tertile were associated with doctor diagnosed allergic rhinitis (OR 12.16, CI 1.23-13.65, $\mathrm{p}<0.001$ ), poor spirometry (FEV1 and FVC $[\mathrm{p}=0.026])$, increased eCO (p 0.046) and nasal lysozyme levels $(\mathrm{p}=0.037)$.

Cladosporum herbarum increased the risk of exercise induced wheezing (OR 3.64, CI 1.42-8.74, $\mathrm{p}=0.043$ ) and nocturnal cough (OR 3.26, CI 1.3-8.2, $\mathrm{p}=$ 0.009). Students were more likely to complain of upper airway symptoms especially cumulative (OR 2.24, CI 1.14-4.85, $\mathrm{p}=0.037)$ and current (OR 2.88, CI 1.32-6.27, $\mathrm{p}=0.006)$ rhinitis which interfered with the child's daily activities (OR 5.03, CI 2.04-12.41, $\mathrm{p}<0.001$ ). Ocular irritation in the previous 12 months was more likely in these students (OR 2.61, CI 1.12-6.67, $\mathrm{p}=0.04$ ) who also had significantly higher nasal ECP levels $(\mathrm{p}=0.037)$. Exposure to Alternaria alternate and Trichoderma Viride were also significantly associated with nasal and skin allergies.

High exposure to Streptomyces spp increased the risk of ocular irritation in the previous 3 months (OR 3.16, CI 1.32-10.32, $\mathrm{p}=0.046$ ) with symptoms more likely to resolve on leaving school (OR 4.76, CI 1.99-11.41, $\mathrm{p}<0.001$ ). There was a significant association with FeNO levels $(p=0.006)$, AMCA $(p=0.014)$, exhaled CO ( $p=0.03)$, nasal lavage MPO $(p=0.03)$ and lysozyme $(p=0.026)$. Students having high exposures to Mycobacterium spp were more likely to complain of current wheezing (OR 3.41, CI 1.23-9.46, p = 0.01), ocular irritation (OR 3.71, CI 1.13-12.16, $\mathrm{p}=0.02$ ) and itchy rash within the previous 3 months (OR 3.64, CI 1.35-13.22, $\mathrm{p}=0.038)$ which resolved away from school (OR 2.59, CI $1.12-6.29, \mathrm{p}=0.031)$.

\subsection{Association between High Exposure to Indoor Allergens and Health in Children}

Students with high exposure to cat allergen within the classroom environment reported both upper and lower respiratory symptoms. Children were more likely to have a diagnosis of asthma (OR 3.74, CI 1.41-9.98, $\mathrm{p}=0.006$ ) and to complain of exercise induced wheezing (OR 3.88, CI 1.85-14.65, $\mathrm{p}=0.048$ ) and a nocturnal cough (OR 4.48, CI 1.76-11.41, $\mathrm{p}=0.001$ ). There was an increased risk of both cumulative (OR 2.94, CI 1.17-7.41, p = 0.018) and current (OR 3.7, CI 1.46- 
9.38, $\mathrm{p}=0.004)$ rhinitis which was more likely to interfere with the child's daily activities (OR 6.75, CI 2.49-18.33, $\mathrm{p}<0.001$ ).

Allergic conjunctivitis (OR 3.1, CI 1.27-8.62, $\mathrm{p}=0.034$ ) and itchy rashes in the previous 3 months (OR 5.47, CI 1.45-20.64, $\mathrm{p}=0.006$ ) were more likely among this cohort of students.

Cat allergen was associated with impaired spirometry (FEV1, FVC p 0.001), increased eCO $(\mathrm{p}<0.001)$ and nasal lavage lysozyme levels $(\mathrm{p}=0.042)$. Students exposed to dog allergen levels were more likely to complain of upper airway atopy mainly current rhinitis (OR 2.1, CI 1.1-4.23, p =0.034), doctor diagnosed allergic rhinitis (OR 4.77, CI 1.62-14.07, $\mathrm{p}=0.002$ ) and rhinoconjunctivitis in the previous 12 months (OR2.79, CI 1.15-6.78, $\mathrm{p}=0.02$ ) which were more likely to interfere with activities of daily living (OR 3.17, CI 1.34-7.57, p = 0.007). Association between school characteristics and high exposure to biological pollutants. Logistic regression analysis has identified specific features in school buildings, classrooms, maintenance and cleaning schedules and the school outdoor environment which had a significant association with exposure to indoor microbiological pollutants (Table 3 ).

\section{Discussion}

Interpretation of microbiology and allergen data in schools is challenging since no established European guidelines exist. The methodology utlised in the current study was similar to the SINHONIE study [10] thus enabling comparison of local data to European results. Madureira et al. [11] has shown that primary schools and child care centres had the highest concentrations of indoor mould with Penicillium and Cladosporium being the most commonly isolated moulds. Children were significantly more susceptible to fungal and bacterial exposure when compared to elderly patients [11]. The SINPHONIE study [10] has shown a large variation in school indoor biological contaminants and allergens making it very difficult to extrapolate data obtained in one European region to another. This is particularly relevant within Maltese schools due to the unique geographical and environmental characteristics of the Maltese Islands.

The Penicillium/Aspergillus/ Paecilomyces/Variotii (PenAsp) group had the highest median indoor concentration however these microorganisms represent a significantly larger group of bacteria and fungi when compared to the other microorganisms analyzed in this study thus possibly explaining the high indoor levels of this group.

Schools 1 and 2 had significantly higher indoor PenAsp levels compared to the other three schools which exceeded the SINPHONIE upper quartile thus suggesting significant contamination of these schools possibly associated with humidity, dampness, poor ventilation and poor cleaning protocols [12]. Similar findings were observed with indoor Aspergillus versicolor, where four schools had indoor levels above the SINPHONIE upper quartile [10].

Schools 4 and 5 had lower levels of PenAsp but higher levels of Mycobacterium spp. The presence of Mycobacteria in settled school dust has not been 
Table 3. Association between schools and bacterial, fungal and allergen exposure.

\begin{tabular}{|c|c|}
\hline School building & Indoor pollutant exposure \\
\hline Southern location & $\begin{array}{l}\text { Students MORE likely to have high exposure to: } \\
\text { - } \quad \text { Cladosporium herbarum } \\
\text { - Streptomyces spp }\end{array}$ \\
\hline Western/rural location & $\begin{array}{l}\text { Students LESS likely to have high exposure to: } \\
\text { - } \quad \text { Mycobacterium spp } \\
\text { - } \quad \text { Streptomyces spp, Alternaria alternate, Cladosporium herbarum, Trichoderma viride }\end{array}$ \\
\hline Sea coast location & $\begin{array}{l}\text { Students MORE likely to have high exposure to: } \\
\text { - PenAsp, Alternaria alternate and Streptomyces spp }\end{array}$ \\
\hline Internal location & $\begin{array}{l}\text { Students MORE likely to have high exposure to: } \\
\text { - Endotoxin and Mycobacteria } \\
\text { - Aspergillus versicolor and Cladosporium herbarum }\end{array}$ \\
\hline School constructed before 1970 & $\begin{array}{l}\text { Students MORE likely to have high exposure to: } \\
\text { - Endotoxin and Mycobacteria spp } \\
\text { - Streptomyces spp }\end{array}$ \\
\hline Schools converted prior to 2006 & $\begin{array}{l}\text { Students MORE likely to have high exposure to: } \\
\text { - Cladosporium herbarum } \\
\text { - Mycobacterium spp }\end{array}$ \\
\hline South facing class windows & $\begin{array}{l}\text { Students MORE likely to have high exposure to: } \\
\text { - Endotoxin and Alternaria alternate }\end{array}$ \\
\hline Small openable class window areas $(<57 \%)$ & $\begin{array}{l}\text { Students MORE likely to have high exposure to: } \\
\text { - } \quad \text { Trichoderma viride, Cladosporium herbarum, Alternaria alternate, } \\
\text { - Streptomyces spp } \\
\text { - Mycobacteria spp and cat allergen }\end{array}$ \\
\hline Classroom windows facing a street & $\begin{array}{l}\text { Students MORE likely to have high exposure to: } \\
\text { - Alternaria alternate and Streptomyces spp }\end{array}$ \\
\hline Direct sunlight in classroom & $\begin{array}{l}\text { Students MORE likely to have high exposure to: } \\
\text { - Trichoderma viride and Cladosporium herbarum }\end{array}$ \\
\hline $\begin{array}{l}\text { Curtained area on classroom } \\
\text { windows less than mean }\left(11 \mathrm{~m}^{2}\right)\end{array}$ & $\begin{array}{l}\text { Students LESS likely to have high exposure to: } \\
\text { - Cladosporium herbarum, Streptomyces spp } \\
\text { - Mycobacteria spp }\end{array}$ \\
\hline Crowded classrooms ( $<2 \mathrm{~m}^{2}$ per child $)$ & $\begin{array}{l}\text { Students MORE likely to have high exposure to: } \\
\text { - Cat and dog allergens }\end{array}$ \\
\hline Humid and visible mould damage in classroom & $\begin{array}{l}\text { Students MORE likely to have high exposure to: } \\
\text { - Mycobacteria spp } \\
\text { - } \quad \text { Cladosporium herbarum, PenAsp, Trichoderma viride }\end{array}$ \\
\hline Class windows kept closed during cleaning & $\begin{array}{l}\text { Students MORE likely to have high exposure to: } \\
\text { - Trichoderma viride and Cladosporium herbarum } \\
\text { - } \quad \text { Cat allergens }\end{array}$ \\
\hline Daily sweeping of class floor & $\begin{array}{l}\text { Students MORE likely to have high exposure to: } \\
\text { - Pen Asp, Trichoderma viride, Cladosporium herbarum and cat allergens }\end{array}$ \\
\hline Class floors washed more than once per week & $\begin{array}{l}\text { Students MORE likely to have high exposure to: } \\
\text { - } \quad \text { Cladosporium herbarum and Streptomyces spp } \\
\text { - Mycobacterium spp }\end{array}$ \\
\hline Class flat furniture surfaces never dusted & $\begin{array}{l}\text { Students MORE likely to have high exposure to: } \\
\text { - } \quad \text { Trichoderma viride, Alternaria alternate, Streptomyces spp } \\
\text { - } \quad \text { Mycobacteria spp }\end{array}$ \\
\hline $\begin{array}{l}\text { Refurbishment of class walls } \\
\text { during previous } 12 \text { months }\end{array}$ & $\begin{array}{l}\text { Students LESS likely to have high exposure to: } \\
\text { - Endotoxin } \\
\text { - PenAsp, Aspergillus versicolor and Cladosporium herbarum } \\
\text { - Cat and dog allergens }\end{array}$ \\
\hline Use of pesticides in school & $\begin{array}{l}\text { Students MORE likely to have high exposure to: } \\
\text { - Endotoxin } \\
\text { Students LESS likely to have high exposure to: } \\
\text { - Streptomyces spp and Mycobacteria spp }\end{array}$ \\
\hline
\end{tabular}


extensively investigated and might be directly associated with poor indoor ventilation and humidity. Mycobacteria might also compete for nutrients and resources with the PenAsp group potentially explaining the inverse relationship between indoor concentrations of these two groups.

\subsection{Indoor Allergens}

Indoor allergens are traditionally associated with atopic disease in humans and their role in schools needs better clarification. Cat and dog allergen levels within several local classrooms were found to be above the SINPHONIE third quartile with a significant association seen between the number of cat owners at home and allergen levels within the classroom. This result confirms the potential risk of transmitting cat allergens from the home environment to school [13] thus exposing other children who do not own pets. Enhanced cleaning and maintenance protocols in local schools are needed together with better education for students and parents on how to minimize exposure to these allergens. School administrators must also ensure that overcrowding of classrooms is avoided.

\subsection{Microbiological Contamination and Health}

There is limited data focusing on the role of bacterial contamination of classrooms and health of school children [14] [15]. This study has shown that high exposures to bacteria and fungi was associated with asthma, rhinitis, rhinoconjunctivitis and atopic eczema. The impaired spirometry, elevated eCO and eNO, narrow nasal cross sectional areas and volumes and increased nasal lavage inflammatory markers confirm the impact these organisms have on the childrens' health. Destruction of bacteria and overcrowding increases levels of endotoxin within the environment [16]. Endotoxin is one of the parameters determining local school indoor air quality due to its association with atopy. Eliminating classroom dust containing endotoxin by adequate cleaning protocols is another crucial factor contributing to improved indoor air quality.

\subsection{Exposure to Microbiological Pollutants and the School Environment}

Both central and southern parts of the Maltese Islands are low lying and the prevailing warm, humid southerly winds [17] might increase school microbiological pollutants. Exposure to rural endotoxins during childhood protects against asthma thus explaining the lower prevalence of symptoms seen in the rural school [18].

Recently built schools or those with recent modifications had lower bacterial and fungal pollutants possibly due to lower humidity levels when compared to older schools [19]. Crowded classrooms favour the transmission of animal allergens from students who have pets at home and contribute to poor air quality resulting in upper airway irritation [20].

Classrooms with south facing windows have higher exposures to endotoxin and fungi due to the prevailing humid southern winds. Small openable window 
areas or window openings obstructed by curtains have poor ventilation characteristics thus favoring indoor microbial contamination.

Road re-suspension of ambient dust [21] is thought to explain the increase in microbial pollutants found in classrooms facing a road. Humidity and water damage were significantly associated with exposure to Mycobacteria, Chladosporum herbarum and PenAsp. Petronella et al. [22] have identified Aspergillus and Alternaria as possible causes of atopy within the school indoor environment especially if humidity is prevalent. Keeping windows closed during cleaning is thought to impair classroom ventilation characteristics resulting in re-suspension and deposition of microbial contaminants. This study has shown that daily floor sweeping in local schools has a negative impact on indoor air quality. Classroom floors with grooves between floor tiles remained wet and humid following floor washing. This microenvironment encourages fungal and bacterial growth since this cleaning regime was associated with high fungal and Mycobacterial exposures. Cleaning had a direct impact on air quality with WHO air quality guidelines recommending regular and cost-effective cleaning and maintenance protocols [12] in schools. No high efficiency particulate air (HEPA) vacuum cleaners are utilized within Maltese schools as recommended [23] and there is no local standardized cleaning protocol. Lower exposures to endotoxins, fungi, cat and dog allergens in settled dust were observed in recently maintained classrooms thus emphasizing the need for regular maintenance programs in schools.

\section{Conclusion}

This is the first time that school dust in Malta has been analysed for microbiological contaminants. Fungi, bacteria, cat and dog allergens have been found to have a direct influence on school indoor air quality in the Maltese Islands when compared to European data. A significant association was observed between endotoxin, bacterial, fungal and cat/dog allergen contamination and atopy. Specific classroom, cleaning and maintenance characteristics have been identified as having a direct impact on indoor air quality. This highlights the importance of considering these pollutants when assessing school indoor air quality and when planning remedial measures to decrease contaminant levels. It is envisaged that this data will provide a reference for future studies within schools and will help in the design of "ideal" schools in Southern Europe having high standards of indoor air quality. It is hoped that this data will contribute to the development of school indoor air quality guidelines which reflect all regions of Europe.

\section{Author Statement}

The submitted manuscript has not been previously published in any form and is not currently under consideration for publication elsewhere.

\section{References}

[1] Smedje, G. and Norbäck, D. (2001) Irritants and Allergens at School in Relation to Furnishings and Cleaning. Indoor Air, 11, 127-133. 
https://doi.org/10.1034/j.1600-0668.2001.110207.x

[2] Meyer, H.W., Würtz, H., Suadicani, P., Valbjørn, O., Sigsgaard, T. and Gyntelberg, F. (2005) Members of a Working Group under the Danish Mold in Buildings program (DAMIB). Molds in Floor Dust and Building-Related Symptoms among Adolescent School Children: A Problem for Boys Only? Indoor Air, 15, 17-24.

[3] Norbäck, D., Wålinder, R., Wieslander, G., Smedje, G., Erwall, C. and Venge, P. (2000) Indoor Air Pollutants in Schools: Nasal Patency and Biomarkers in Nasal Lavage. Allergy, 55, 163-170. https://doi.org/10.1034/j.1398-9995.2000.00353.x

[4] Simoni, M., Cai, G.H., Norback, D., Annesi-Maesano, I., Lavaud, F., Sigsgaard, T., et al. (2011) Total Viable Molds and Fungal DNA in Classrooms and Association with Respiratory Health and Pulmonary Function of European Schoolchildren. Pediatric Allergy and Immunology, 22, 843-852.

https://doi.org/10.1111/j.1399-3038.2011.01208.x

[5] ISAAC Steering Committee (1998) Worldwide Variation in Prevalence of Symptoms of Asthma, Allergic Rhinoconjunctivitis, and Atopic Eczema: ISAAC. The International Study of Asthma and Allergies in Childhood (ISAAC). The Lancet, 351, 1225-1232.

[6] Holst, G., Høst, A., Doekes, G., Meyer, H.W., Madsen, A.M. and Sigsgaard, T. (2014) Determinants of House Dust, Endotoxin, and $\beta$ - $(1 \rightarrow 3)$-d-glucan in Homes of Danish Children. Indoor Air, 11, 121-143.

[7] Kaarakainen, P., Rintala, H., Vepsalainen, A., Hyvarinen, A., Nevalainen, A. and Meklin, T. (2009) Microbial Content of House Dust Samples Determined with qPCR. Science of the Total Environment, 407, 4673-4680.

[8] Norbäck, D., Markowicz, P., Cai, G.H., Hashim, Z., Ali, F., Zheng, Y.W., et al. (2014) Endotoxin, Ergosterol, Fungal DNA and Allergens in Dust from Schools in Johor Bahru, Malaysia-Associations with Asthma and Respiratory Infections in $\mathrm{Pu}$ pils. PLoS ONE, 9, e88303. https://doi.org/10.1371/journal.pone.0088303

[9] Parvaneh, S., Johansson, E., Elfman, L.H. and van Hage-Hamsten, M. (2002) An ELISA for Recombinant Lepidoglyphus Destructor, Lep d 2, and the Monitoring of Exposure to Dust Mite Allergens in Farming Households. Clinical \& Experimental Allergy, 32, 80-86. https://doi.org/10.1046/j.0022-0477.2001.01255.x

[10] Csobod, É., Annesi-Maesano, I., Carrer, P., Kephalopoulos, S., Madureira, J., Rudnai, P., de Oliveira Fernandes, E., Barrero-Moreno, J., Beregszászi, T., Hyvärinen, A., Moshammer, H., Norback, D., Páldy, A., Pándics, T., Sestini, P., Stranger, M., Täubel, M., Varró, M.J., Vaskovi, E., Ventura, G. and Viegi, G. (2014) SINPHONIE (Schools Indoor Pollution and Health Observatory Network in Europe). Final Report, Co-Published by the European Commission's Directorates General for Health and Consumers and Joint Research Centre, Luxembourg.

[11] Madureira, J., Paciencia, I., Cavaleiro Rufo, J., Pereira, C., Teixeira, J.P. and Oliveira, F.E. (2015) Assessment and Determinants of Airborne Bacterial and Fungal Concentrations in Different Indoor Environments: Homes, Child Day-Care Centres, Primary Schools and Elderly Care Centres. Atmospheric Environment, 109, 139-146.

[12] World Health Organisation (2009) WHO Guidelines for Indoor Air Quality: Dampness and Mould. WHO Regional Office for Europe, Copenhagen.

[13] Norback, D., Sestini, P., Elfman, L., Wieslander, G., Sigsgaard, T., Canciani, M., et al. (2006) Health Effects of the School Environment (HESE): Indoor Environment in Primary Schools in Italy, France, Denmark, Norway and Sweden. Healthy Building, Lisboa.

[14] Smedje, G., Norbäck, D. and Edling, C. (1997) Asthma among Secondary School- 
children in Relation to the School Environment. Clinical \& Experimental Allergy, 27, 1270-1278. https://doi.org/10.1111/j.1365-2222.1997.tb01171.x

[15] Kim, J.L., Elfman, L., Mi, Y., Wieslander, G., Smedje, G. and Norback, D. (2007) Indoor Molds, Bacteria, Microbial Volatile Organic Compounds and Plasticizers in Schools-Associations with Asthma and Respiratory Symptoms in Pupils. Indoor Air, 17, 153-163. https://doi.org/10.1111/j.1600-0668.2006.00466.x

[16] Annesi-Maesano, I., Baiz, N., Banerjee, S., Rudnai, P., Rive, S. and SINPHONIE Group (2013) Indoor Air Quality and Sources in Schools and Related Health Effects. Journal of Toxicology and Environmental Health. Part B, Critical Reviews, 16, 491-550. https://doi.org/10.1080/10937404.2013.853609

[17] Galdies, C. (2011) The Climate of Malta: Statistics, Trends and Analysis, 1951-2010. National Statistics Office, Valletta.

[18] Lawson, J., Dosman, J., Rennie, D., Beach, J., Newman, S., Crowe, T. and Senthilselvan, A. (2012) Endotoxin as a Determinant of Asthma and Wheeze among Rural Dwelling Children and Adolescents: A Case-Control Study. BMC Pulmonary Medicine, 12, 56. https://doi.org/10.1186/1471-2466-12-56

[19] Mori, M., Hara, K., Miyakita, T. and Ishitake, T. (2011) Association of Indoor Air Quality with Physical Health of Users in a Newly Built School Building in a University. Nihon Eiseigaku Zasshi, 66, 122-128. https://doi.org/10.1265/jjh.66.122

[20] Salo, P.M., Sever, M.L. and Zeldin, D.C. (2009) Indoor Allergens in School and Daycare Environments. The Journal of Allergy and Clinical Immunology, 124, 185-194. https://doi.org/10.1016/j.jaci.2009.05.012

[21] World Health Organization (2005) Air Quality Guidelines Global Update 2005: Particulate Matter, Ozone, Nitrogen Dioxide and Sulfur Dioxide.

[22] Petronella, S.A., Thomas, R., Stone, J.A., Goldblum, R.M. and Brooks, E.G. (2005) Clearing the Air: A Model for Investigating Indoor Air Quality in Texas Schools. Journal of Environmental Health, 67, 35-42.

[23] Bernstein, J.A., Levin, L., Crandall, M.S., Perez, A. and Lanphear, B. (2005) A Pilot Study to Investigate the Effects of Combined Dehumidification and HEPA Filtration on Dew Point and Airborne Mold Spore Counts in Day Care Centers. Indoor Air, 15, 402-407. https://doi.org/10.1111/j.1600-0668.2005.00379.x

\section{Submit or recommend next manuscript to SCIRP and we will provide best service for you:}

Accepting pre-submission inquiries through Email, Facebook, LinkedIn, Twitter, etc. A wide selection of journals (inclusive of 9 subjects, more than 200 journals)

Providing 24-hour high-quality service

User-friendly online submission system

Fair and swift peer-review system

Efficient typesetting and proofreading procedure

Display of the result of downloads and visits, as well as the number of cited articles

Maximum dissemination of your research work

Submit your manuscript at: http://papersubmission.scirp.org/

Or contact gep@scirp.org 